\title{
Acute hepatic failure: University of Toronto experience
}

\author{
GA LEVY, MD, FRCPC
}

GA LEVY. Acute hepatic failure: University of Toronto experience. Can J Gastroenterol 1993;7(7):542-544. Fulminant hepatic failure (FHF) is a serious disorder of the liver that is associated with a mortality of 80 to $90 \%$. Admission of patients to specialized liver intensive care units has resulted in an improvement of survival from 10 to $30 \%$. To date, however, no specific medical therapy has proven to be effective, and liver transplantation is the main form of therapy for these patients. Previously, the author demonstrated that prostaglandins could alter the course of FHF in an experimental animal model caused by the coronavirus, murine hepatitis virus strain 3. Furthermore, in an uncontrolled trial in patients with this disorder, overall survival was $71 \%$ in patients treated with intravenous prostaglandins. Based upon these initial results, a prospective randomized controlled trial of intravenous prostaglandin $E_{1}$ compared with placebo was performed in 41 patients. The overall results showed no improvement in survival of the prostaglandin-treated patients (40\%) compared with the controls who were treated with placebo (38\%). However, in the patients with FHF caused by acetaminophen, survival was higher in the prostaglandin-treated group (54.5\%) compared with the placebo-treated patients $(37.5 \%)$. Furthermore, if treatment with prostaglandin $E_{1}$ was initiated within 10 days of first symptoms, survival was $73 \%$, compared with $16 \%$ survival if treatment was delayed for more than four days. These results suggest a potential role for prostaglandins in the early management of patients with FHF, especially due to acetaminophen toxicity.

Key Words: Fulminant hepatic failure, Liver transplantation, Prostaglandin, Therapy

\section{Insuffisance hépatique aiguë: expérience menée à l'Université de Toronto}

RÉSUMÉ: L'insuffisance hépatique fulminante est une maladie grave du foie qui est associée à un taux de mortalité de l'ordre de $80 \%$ à $90 \%$. L'admission des patients dans les unités de soins intensifs spécialisés pour le foie a donné lieu à une amélioration du taux de survie de $10 \%$ à $30 \%$. Jusqu'à présent, cependant, aucune thérapeutique médicale spécifique ne s'est révélée efficace et la transplantation hépatique demeure la principale forme de traitement pour ces patients. Auparavant, les auteurs ont démontré que les prostaglandines pouvaient altérer la

Division of Gastroenterology, Multi-Organ Transplantation, University of Toronto,

Toronto, Ontario

Correspondence and reprints: Dr G Levy, Head, Division of Gastroenterology, University of Toronto, 621 University Avenue, Toronto, Ontario M5G 2C4. Telephone (416) 340-5166
$\mathrm{F}$ ULMINANT HEPATIC FAILURE (FHF) is defined as the development of severe impairment of hepatocellular function in an individual who has no evidence of previous liver disease. It has been recently subdivided into three subgroups: hyperacute, acute and subacute. Hyperacute FHF is defined as the onset of FHF less than 48 to $72 \mathrm{~h}$ after initial symptoms, acute is defined as the onset of illness less than eight weeks from the onset of symptoms and subacute is defined as the onset of liver failure within eight to 28 weeks from the onset of initial symptoms. The mortality of FHF of all etiologies can be as high as $80 \%$ as the patient develops grade III to IV hepatic encephalopathy (1).

Since the recognition of this disease entity in 1970 by Trey and Davidson, there have been a number of developments which have resulted in new treatments for these patients. The group at King's College, London, United Kingdom, headed by Roger Williams established the principle of admission of such patients to a defined liver unit. Based upon this, advances in treatment - including charcoal hemoperfusion, introduction of intracranial pressure monitors, infusion of glucose and insulin, prostacyclins and anticoagulants - have advanced our understanding of this disease entity and, in some cases, improved survival (2). In 
progression de l'insuffisance hépatique fulminante dans le cadre d'un modèle animal expérimental provoqué par le coronavirus et la souche 3 du virus de l'hépatite murine. De plus, dans un essai non contrôlé chez des patients atteints de cette maladie, le taux de survie global a été de $71 \%$ chez les patients traités avec des prostaglandines intraveineuses. Sur la base de ces résultats initiaux, une étude contrôlée randomisée prospective portant sur la prostaglandine $\mathrm{E}_{1} \mathrm{com}$ parée à du placebo a été effectuée auprès de 41 patients. Les résultats globaux n'ont révélé aucune amélioration du taux de survie chez les patients traités avec la prostaglandine ( $40 \%$ ) en comparaison avec les contrôles qui ont été traités avec du placebo ( $38 \%)$. Cependant, chez les patients atteints d'une insuffisance hépatique fulminante causée par l'acétaminophène, le taux de survie s'est révêlé plus haut chez les sujets traités avec la prostaglandine $(54,5 \%)$ que chez les patients qui recevaient du placebo $(37,5 \%)$. En outre, si le traitement avec la prostaglandine $E_{1}$ avait été amorcé dans les 10 jours suivant les premiers symptômes, le taux de survie était de $73 \%$, contre $16 \%$ si le traitement était retardé de plus de 4 jours. Ces résultats donnent à penser que les prostaglandines auraient un rôle potentiel dans le traitement précoce des patients atteints d'insuffisance hépatique fulminante, particulièrement attribuable à une intoxication à l'acétaminophène.

1980, Benhamou (3) defined the importance of measurements of coagulation factors $\mathrm{V}$ and $\mathrm{VII}$ as discriminants of survival. O'Grady (4) used a multivariate analysis in 1989 to determine prognostic indicators for patients with severe forms of FHF.

In the 1980s it became apparent that liver transplantation could be effective for treatment of patients with FHF, and this has become the main form of therapy for severe FHF (5).

\section{THERAPY AT THE UNIVERSITY OF TORONTO}

Liver transplantation: With the establishment of a liver transplant program in 1985 at the University of Toronto, patients with FHF became candidates for liver transplantation. Early transplant experience of the author's group was patients with FHF constituted $28 \%$ of total liver transplantation. As of 1991, this group has transplanted 26 patients with FHF; the survival rate, $48 \%$, is in keeping with the rates reported by other institutions. On further analysis of these data, however, it has become apparent that patients with status II and III hepatic encephalopathy do well following liver transplantation (78\% survival) whereas patients with deep stage IV hepatic encephalopathy do poorly (26\% survival).

With these rates in mind, the University of Toronto looked for other forms of treatment to help patients with FHF.

\section{PROSTAGLANDINS AND FHF}

Animal experiments: The author's group (6) has previously reported that 16,16 dimethyl prostaglandin $\mathrm{E}_{2}$ (dmPGE2), a known cytoprotective agent, was able to alter the course of FHF in an experimental model of fulminant viral hepatitis, a murine hepatitis virus type 3 . Whereas fully susceptible animals infected with the virus develop histological and biochemical evidence of fulminant hepatic hepatitis - as evidenced by massive hepatic necrosis with hypoglycemia and metabolic acidosis - animals treated with $\mathrm{dmPGE}_{2}$, either before or after infection, demonstrated a marked reduction in both histological and biochemical evidence of liver damage, as characterized by normal blood glucose, total carbon dioxide and alanine aminotransferase determinations. The effect of $\mathrm{dmPGE}_{2}$ was specific as another prostaglandin, $\mathrm{PGF}_{2 \mathrm{a}}$, demonstrated no such cytoprotective effects.

Clinical experience: The results of animal experiments led Sinclair et al (7) to an open trial to study the effect of prostaglandins on patients with fulminant and subfulminant viral hepatitis. Seventeen patients presented with FHF secondary to hepatitis A, B and C. Fourteen of these patients had stage III or IV hepatic encephalopathy. All patients had high levels of aspartate transaminase and bilirubin, and markedly abnormal prothrombin times and partial thromboplastin times. Intravenous $\mathrm{PGE}_{1}$ was initiated within 24 to $48 \mathrm{~h}$ of presentation and a marked improvement in hepatic synthetic function was noted in the vast majority of patients. Overall survival was $71 \%$ in this series. None of the patients with hepatitis B or $A$ virus infection flared upon tapering of therapy; however, a relapse was noted in patients with hepatitis $C$, necessitating further therapy. Two of the patients required prolonged oral prostaglandins, but are free from disease six months later. These initial results suggest that treatment with prostaglandins of the $\mathrm{E}$ series may be beneficial in patients with fulminant and subfulminant hepatitis.

Based upon these initial results, Sheiner and colleagues (8) performed a prospective randomized control trial of intravenous $\mathrm{PGE}_{1}$ compared with placebo at the University of Toronto. Although it was calculated that $52 \mathrm{pa}-$ tients would be required if the expected mortality was reduced from 80 to $40 \%$, after three years with recruitment declining the trial was stopped with an enrolment of 41 patients. The patients ranged in age from three to 66 years; 16 patients were male and 25 were female. The etiology was viral (20 patients), drugs/toxins (19) and ischemia (two). Stages of hepatic encephalopathy on admission were stage $I$ and II, $(n=25)$, stage III $(n=10)$, stage IV $(n=6)$. At initiation of therapy, $73 \%$ of the patients had deteriorated to stage IV. Failure of treatment was defined as continued deterioration on therapy, and open-label PGE1 was initiated and patients were listed for transplantation.

The overall results showed that eight of $20 \mathrm{PGE}_{1}$-treated patients (40\%) versus eight of 21 placebotreated patients $(38 \%)$ survived (not statistically different). Based on initial presentation of hepatic encephalopathy in grades I and II, $50 \%$ survival was seen in the $\mathrm{PGE}_{1}$ group, whereas only $38 \%$ was seen in the placebo group. The mortality rates for viral hepatitis were similar in the placebo and prostaglandin groups, but survival in the drug/toxin hepatitis group was significantly higher than in the placebo group ( $54.5 \%$ versus $37.5 \%)$. Furthermore, regardless of the initial randomi- 
zation, if treatment with $\mathrm{PGE}_{1}$ was initiated within 10 days of first symptoms, survival was $73 \%$ (eight of 11 ) compared with $16 \%$ (three of 18 ) if treatment was delayed for more than 14 days $(\mathrm{P}<0.001)$.

Although this trial failed to show an overall benefit for $\mathrm{PGE}_{1}$ therapy in FHF, the results support the facts that $\mathrm{PGE}_{1}$ may be of benefit if started early (less than 10 days) in the course of FHF and appears to be more useful in drug-1 toxin-induced FHF.

\section{CONCLUSIONS}

There have been several significant advances in the understanding of the pathogenesis and treatment of FHF. Early recognition of these patients in transfer to a liver unit has resulted in a marked improvement in survival. Fur- thermore, liver transplantation can be successful in these patients even when the patients lapse into deep coma. $\mathrm{Fi}$ nally, recent data suggest a role for prostaglandins and prostacyclins in the therapy of patients with FHF, especially when started early.

\section{REFERENCES}

1. Martin P, Pappas SC. Fulminant hepatic failure. Dig Dis Sci 1990;8:138.

2. Rakela J, Kurtz, SB, McCarthy JT, et al. Fulminant Wilson's disease treated with postdilutional hemofiltration and orthotopic liver transplantation. Gastroenterology 1986;90:2004-7.

3. Bernuau J, Rueff B, Benhamou FP. Fulminant and subfulminant liver failure definitions and causes. Semin Liver Dis 1986;6:97.

4. O'Grady JG, Alexander GJM, Hayllar KM, Williams R. Early indicators of prognosis in fulminant hepatic failure. Gastroenterology 1989;97:439-45

5. Peleman RR, Gavaler JS, Van Thiel D, et al. Orthotopic liver transplantation for acute and subacute hepatic failure in adults. Hepatology 1987;7:484-9.

6. Abecassis M, Falk JA, Makowka L, Dindzans VJ, Falk RE, Levy GA. 16,16 dimethyl prostaglandin $\mathrm{E}_{2}$ prevents the development of fulminant hepatitis and blocks the induction of monocyte/ macrophage procoagulant activity after murine hepatitis virus strain 3 infection. J Clin Invest 1987;80:881-9.

7. Sinclair SB, Greig PD, Blendis LM, et al. Biochemical and clinical response to fulminant viral hepatitis to administration of prostaglandin $\mathrm{E}$. J Clin Invest 1989;84:1063-9.

8. Sheiner P, Sinclair SB, Greig PD, Logan A, Blendis LM, Levy GA. Randomized control trial of prostaglandin $\mathrm{E}_{2}\left(\mathrm{PGE}_{2}\right)$ in the treatment of fulminant hepatic failure (FHF). Hepatology 1992;16:88A. 


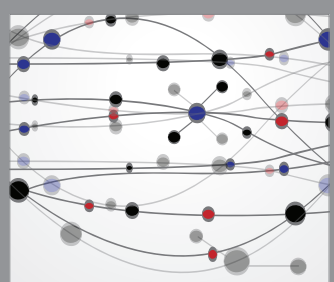

The Scientific World Journal
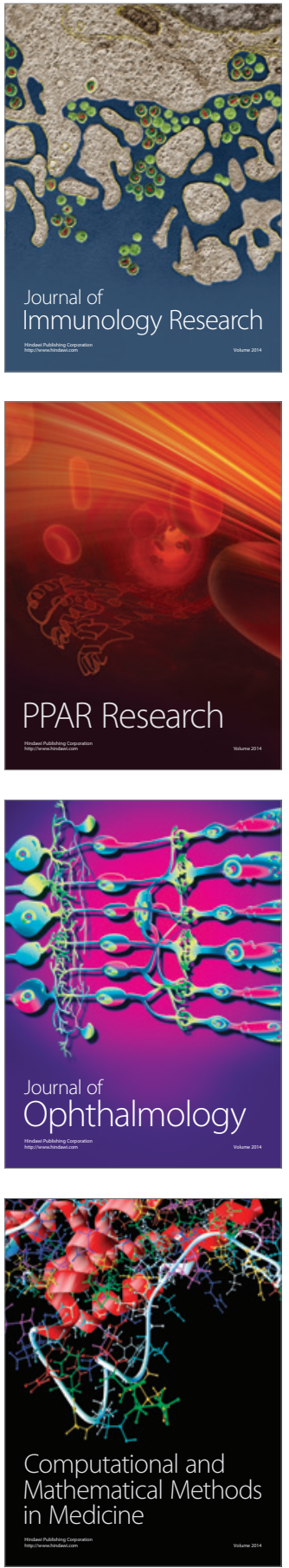

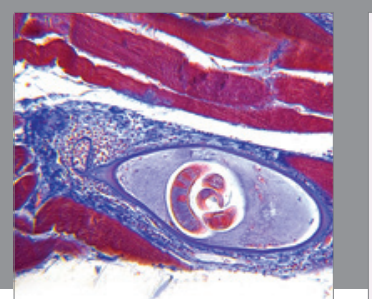

Gastroenterology Research and Practice

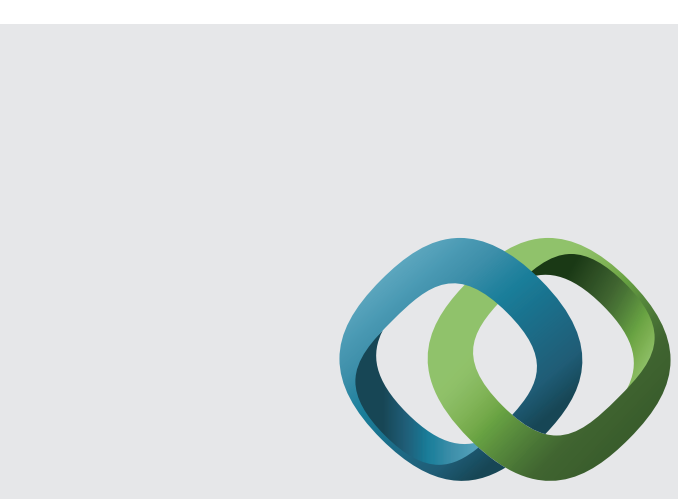

\section{Hindawi}

Submit your manuscripts at

http://www.hindawi.com
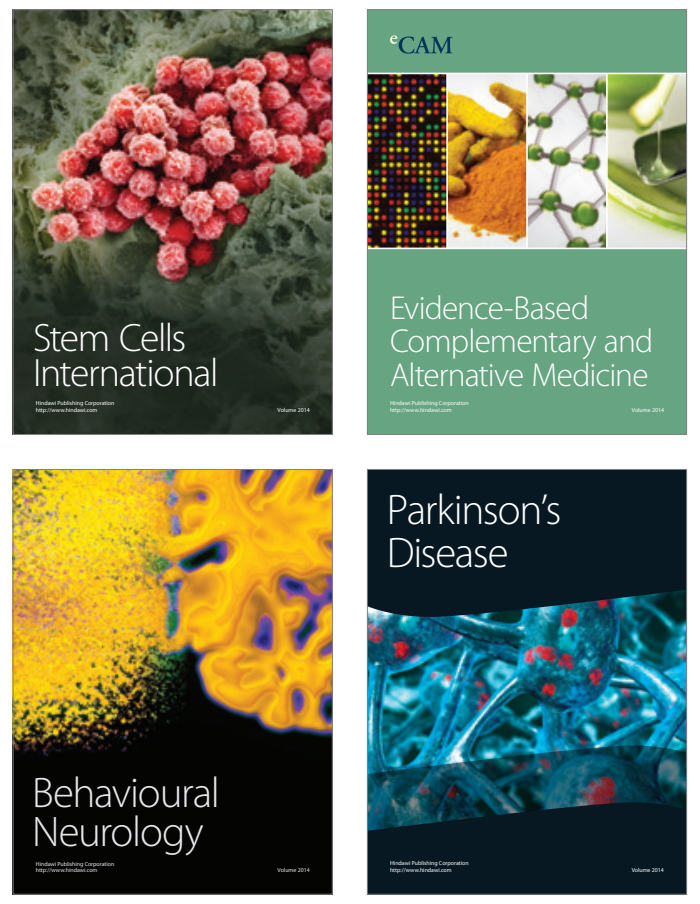
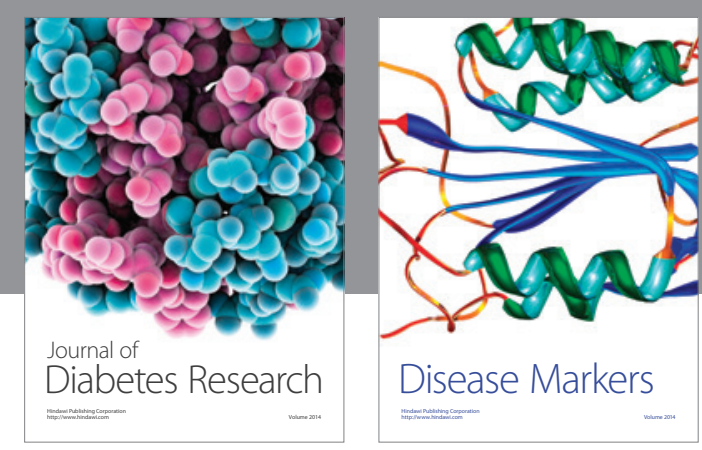

Disease Markers
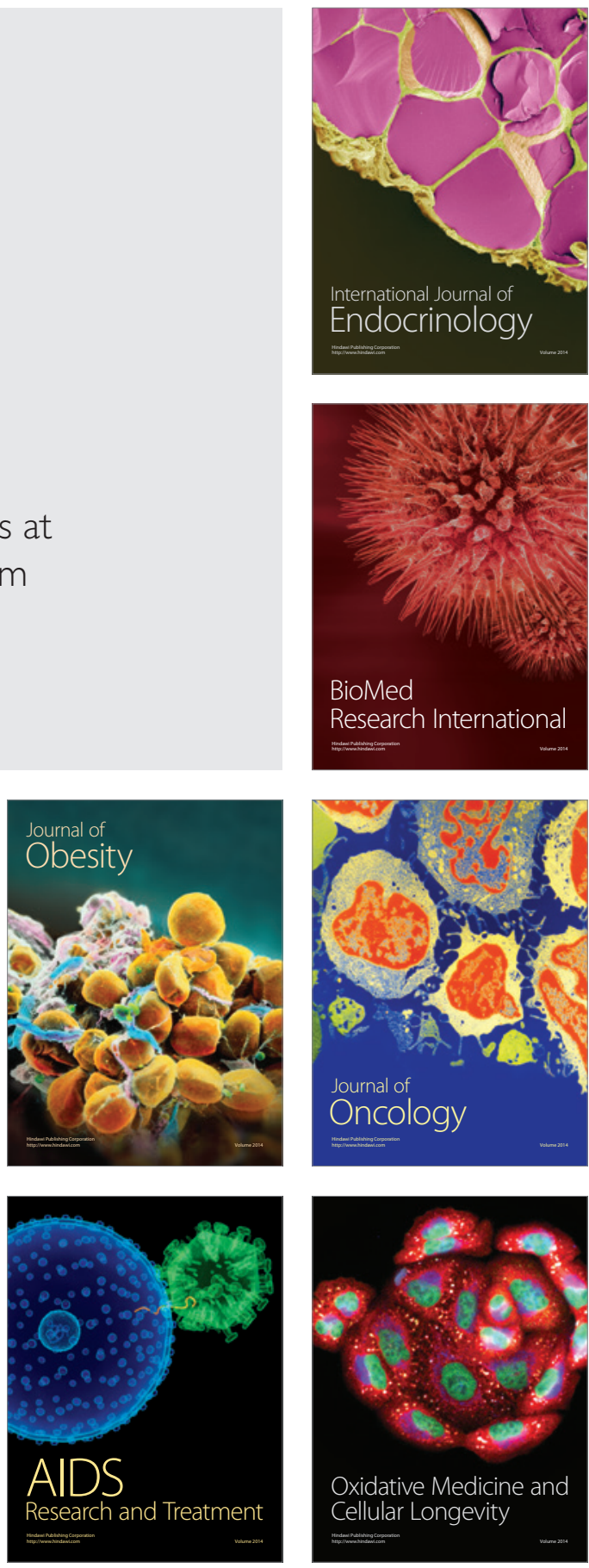